Guiding Light

\title{
The Qur'an and the Sunnah on the Civilization Value of Cleanliness
}

\section{Comments by 'AbdulHamid A. AbüSulaymän}

Translation

In the name of Allah, Most Gracious, Most Merciful.

1. And $\mathrm{He}$ it is Who sends

The Winds as heralds

Of glad tidings, going before

His Mercy, and We send down

Pure water from the sky.

Al Furqān (25:48)

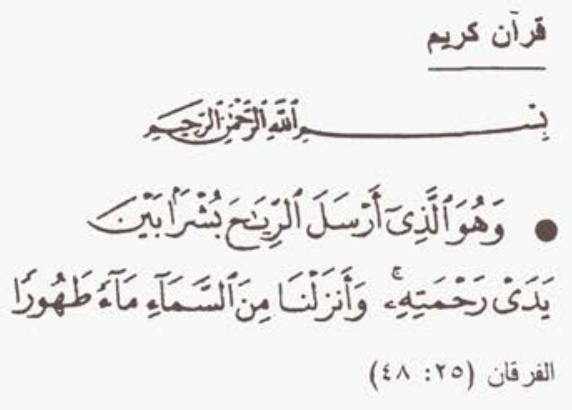

2. Remember He covered you

With drowsiness,

To give you calm as from

Himself, and He caused

Rain to descend on you

From Heaven, to clean you

Therewith, to remove from you

The stain of Satan,

To strengthen your hearts,

And to plant your feet

Firmly therewith.

Al Anfal (8:11)

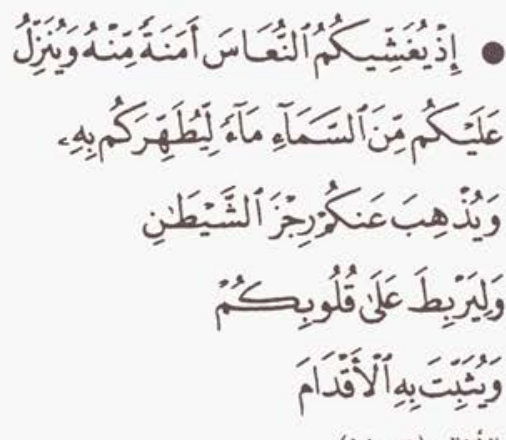

الأنفال (1: (1)

3. O thou wrapped up

(In a mantle)!

Arise and deliver thy warning!

And thy Lord

Do thou magnify!

And thy garments

Keep free from stain!

And all abomination shun!

Al Muddaththir (74:1-5)

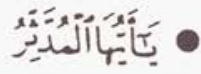

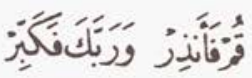

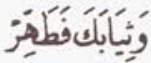

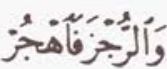

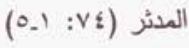

4. O ye who believe!

When ye prepare

For prayer, wash

Your faces, and your hands

(And arms) to the elbows;

Rub your heads (with water);
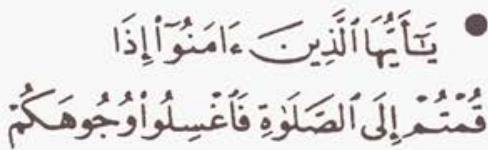

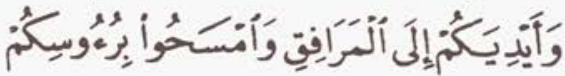


And (wash) your feet

To the ankles.

If ye are in a state

Of ceremonial impurity,

Bathe your whole body.

But if ye are ill,

Or on a journey,

Or one of you cometh

From offices of nature,

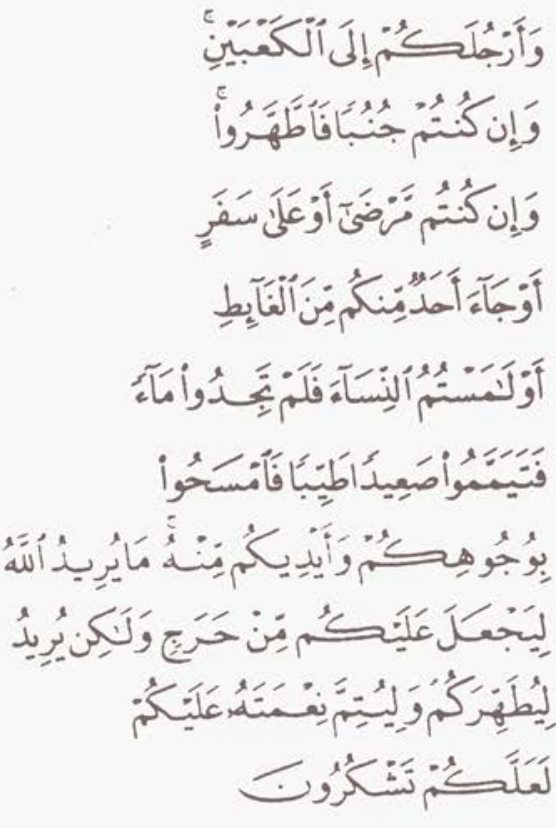

Or ye have been

In contact with women,

And ye find no water,

Then take for yourselves

Clean sand or earth,

And rub therewith

Your faces and hands.

Allah doth not wish

To place you in a difficulty,

But to make you clean,

And to complete

His favour to you,

That ye may be grateful.

Al Mäidah (5:6)

5. And they will ask thee about

(woman's) monthly courses. Say: "It

المائدة (0:

is a vulnerable condition. Keep,

therefore, aloof from women during their monthly courses, and do not draw near unto them until they are cleansed; and when they are cleansed, go in unto them as God has bidden you to do." Verily, God loves those who turn unto Him in repentance, and He loves those who keep themselves pure.

Al Baqarah (2:222)

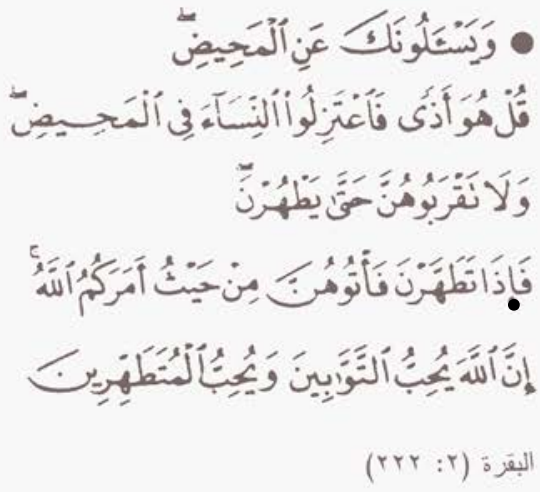

In the above verses, the Qur'an speaks of cleanliness (tahärah) in a physical sense and also informs us that the rain water which Allah causes to fall from the sky is clean and meant for drinking and cleaning.

In these verses, the Qur'an orders the Prophet and, by implication, the Muslims to keep their clothes clean. Allah requires Muslims to clean those bodily parts which are usually exposed to dirt before their daily prayers. He commands them to bathe in order to cleanse their entire body after they sleep with their spouses. The Qur'an also requires Muslim women to cleanse their bodies through washing after their monthly periods. 
6. Of their goods take alms,

That so thou mightest

Purify and sanctify them;

And pray on their behalf.

Verily thy prayers are a source

Of security for them;

And Allah is One

Who heareth and knoweth.

Al Tawbah (9:103)

7. Behold! the angeis said:

"O Mary! Allah hath chosen thee And purified thee-chosen thee

Above the women of all nations."

Al Imrän (3:42)

8. O Messenger! let not

Those grieve thee, who race

Each other into Unbelief:

(Whether it be) among those

Who say: "We believe"

With their lips but

Whose hearts have no faith;

Or it be among the Jews-

Men who will listen

To any lie-will listen

Even to others who have

Never so much as come

To thee. They change the words

From their (right) times

And places: they say,

"If ye are given this,

Take it, but if not,

Beware!" If any one's trial

is intended by Allah, thou hast

No authority in the least

For him against Allah.

For such-it is not

Allah's will to purify

Their hearts. For them

There is disgrace

In this world, and

In the Hereafter

A heavy punishment.

Al Mäidah (5:41)
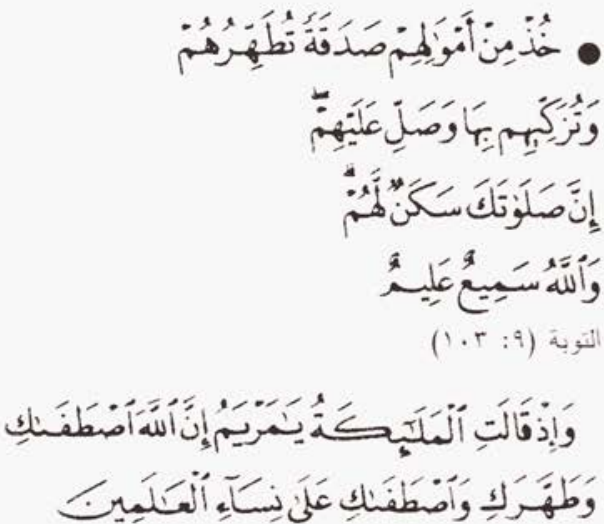

$$
\text { أل عمران (r: }
$$
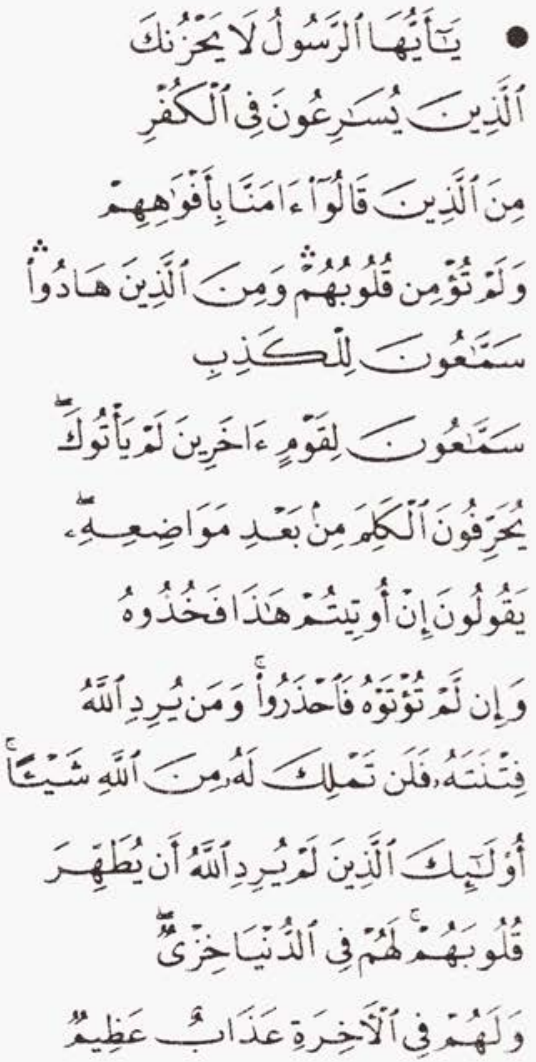

(:) :0) (:

9. O, Consorts of the Prophet!

Ye are not like any

Of the (other) women:

If ye do fear (Allah),

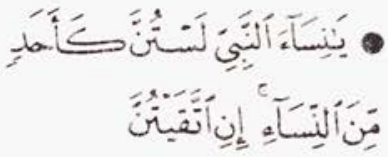


Be not too complaisant

Of speech, lest one

In whose heart is

A disease should be moved

With desire: but speak ye

A speech (that is) just.

And stay quietly in

Your houses, and make not

A dazzling display, like

That of the former Times

Of Ignorance; and establish

Regular Prayer, and give

Regular Charity; and obey

Allah and His Messenger.

And Allah only wishes

To remove all abomination

From you, ye Members

Of the Family, and to make

You pure and spotless.

Al Ahzäb (33:32-33)

10. O ye who believe!

Intoxicants and gambling,

(Dedication of) stones,

And (divination by) arrows,

Are an abomination-

Of Satan's handiwork;

Eschew such (abomination),

That ye may prosper.

Satan's plan is (but)

To excite enmity and hatred

Between you, with intoxicants

And gambling, and hinder you

From the remembrance

Of Allah, and from prayer:

Will ye not then abstain?

Al Māidah (5:90-91)
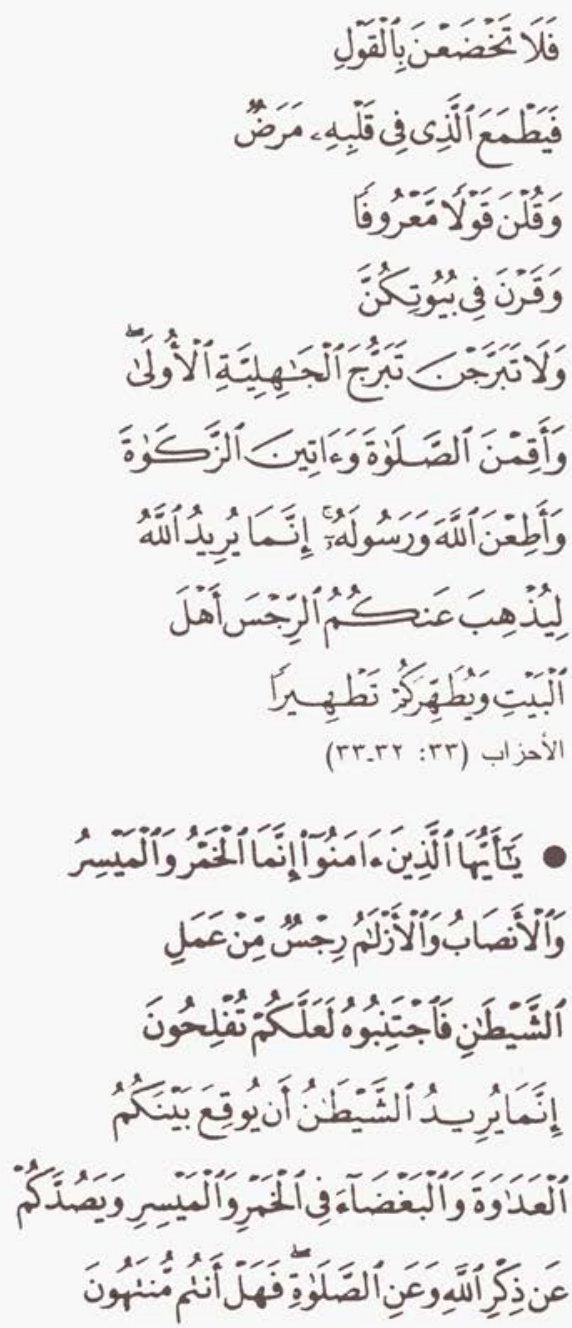

المائدة (0: :9.9)

In these verses, the Qur'an is now peaking of moral and spiritual cleanliness and purity. These verses show how, in both a spiritual and moral sense, good deeds clean and purify the human being. In the last verse mentioned above, the Qur'an uses the word rijs (filth) to describe spiritual and moral impurity, which gives the concept of tahāahah (purity) a wider and deeper meaning to encompass the inner and outer as well as physical, moral, and spiritual cleanliness and purity. 
11. We also (sent) Lüt:

He said to his people:

"Do ye commit lewdness

Such as no people

In creation (ever) committed

Before you?

For ye practice your lusts

On men in preference

To women: Ye are indeed

A people transgressing

Beyond bounds."

And his people gave

No answer but this:

They said, "Drive them out

Of your city; these are

Indeed men who want

To be clean and pure!"

But We saved him

And his family, except

His wife: she was

Of those who lagged behind.

And we rained down on them

A shower (of brimstone):

Then see what was the end

Of those who indulged

In sin and crime!

Al Arräf (7:80-84)

12. (We also sent) Lūt

(As a messenger): behold,

He said to his people,

"Do ye do what is shameful

Though ye see (its iniquity)?

Would ye really approach men

In your lusts rather than

Women? Nay, ye are

A people (grossly) ignorant!

But his people gave

No other answer but this:

They said, "Drive out

The followers of Lüt from

Your city: these are

Indeed men who want

To be clean and pure!"

But We saved him

And his family, except

His wife: her We destined

To be of those

Who lagged behind.

And We rained down on them

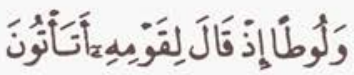

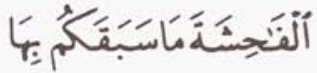
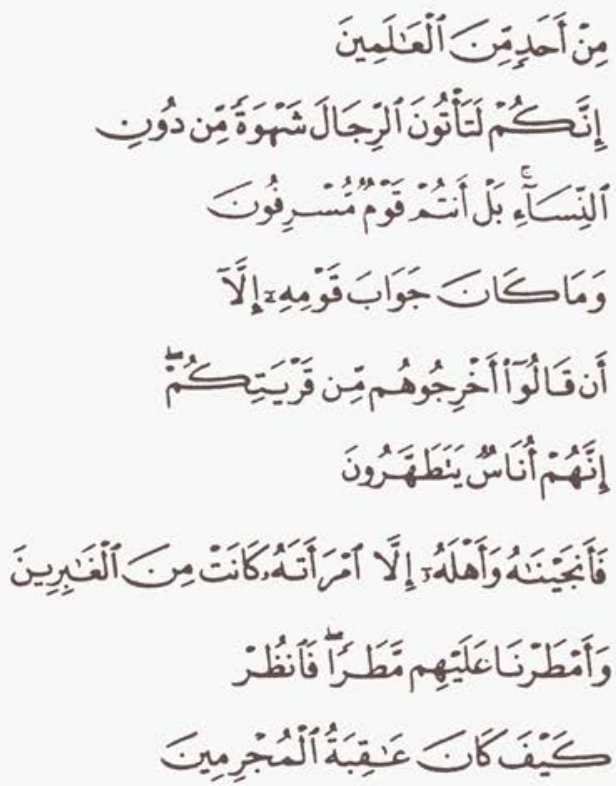

الأعراف (v: .^ی_^)
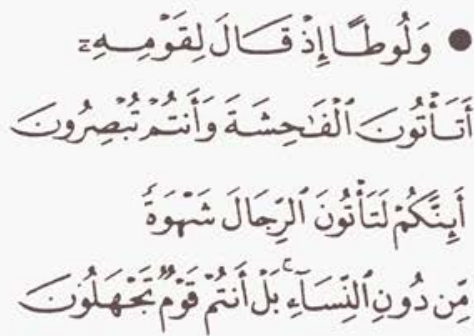

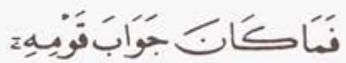

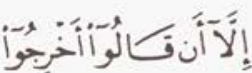

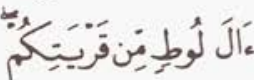

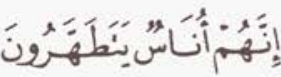

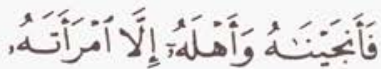

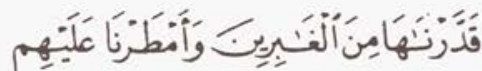


A shower (of brimstone):

And evil was the shower

On those who were admonished

(But heeded not)!

Al Naml (27:54-58)
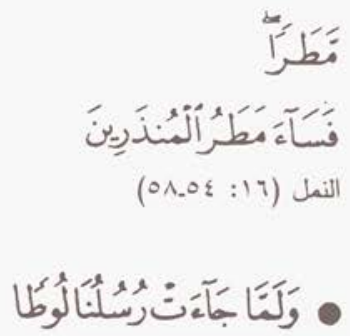

Came to Lüt, he was

Grieved on their account

And felt himself powerless

(To Protect) them. He said:

"This is a distressful day."

And his people came

Rushing towards him,

And they had been long

In the habit of practicing

Abominations. He said:

"O my people! Here are

My daughters; they are purer

For you (if ye marry)!

Now fear Allah, and cover me not

With shame about my guests!

Is there not among you

A single right-minded man?"

They said: "Well dost thou

Know we have no need

Of thy daughters: indeed

Thou knowest quite well

What we want!"

He said: "Would that I

Had power to suppress you

Or that I could betake

Myself to some powerful support."

(The Messengers) said: "O Lüt!

We are Messengers from thy Lord!

By no means shall they

Reach thee! Now travel

With thy family while yet

A part of the night remains,

And let not any of you

Look back: but thy wife

(Will remain behind):

To her will happen

What happens to the people.

Morning is their time appointed:

Is not the morning nigh?"

When Our decree issued,
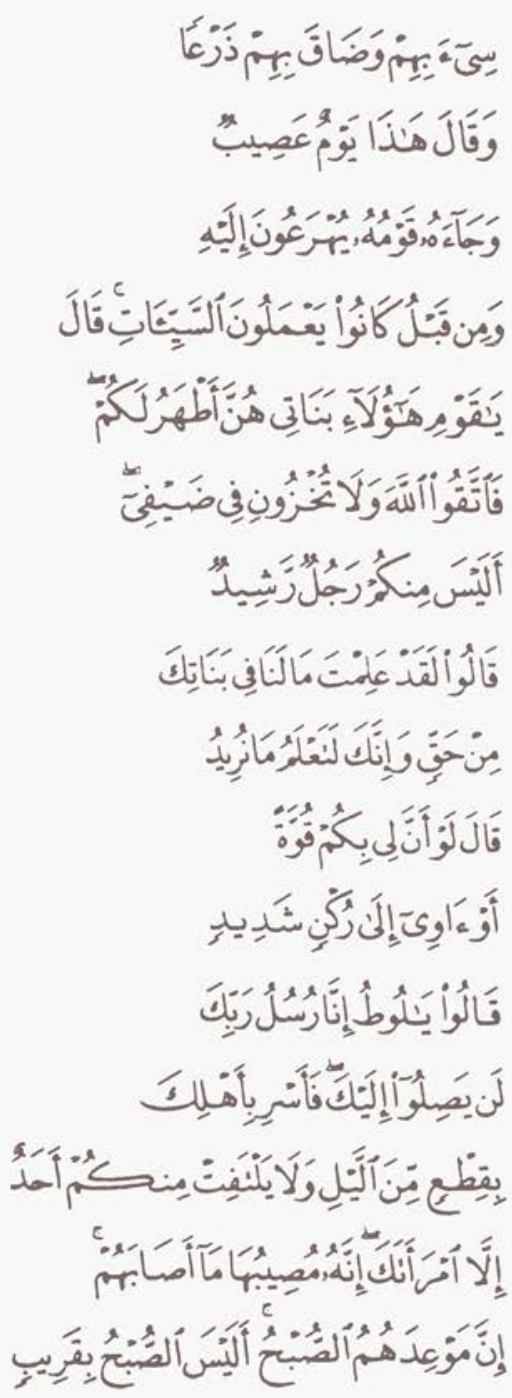

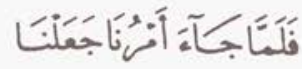

We turned (the cities)

Upside down, and rained down

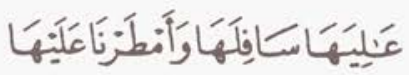


On them brimstones

Hard as baked clay,

Spread, layer on layer-

Marked from thy Lord:

Nor are they ever far

From those who do wrong!

Hüd (11:77-83)

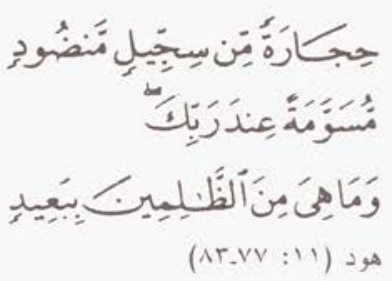

14. Remember We made the House

A place of assembly for men

And a place of safety;

And take ye the Station

Of Abraham as a place

Of prayer; and We covenanted

With Abraham and Ismāil

That they should sanctify

My House for those who

Compass it round, or use it

As a retreat, or how, or

Prostrate themselves (therein

In prayer).

Al Baqarah (2:125)
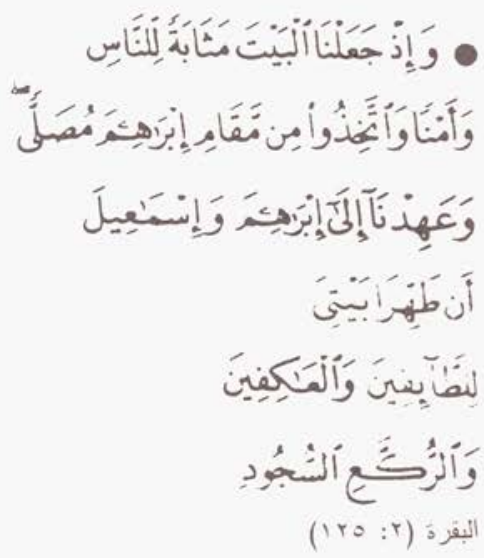

15. "O! thou wrapped up

(In a mantle)!

Arise and deliver thy warning!

And thy Lord

Do thou magnify!

And thy garments

Keep free from stain!

And all abomination shun!

Nor expect, in giving,

Any increase (for thyself)!

But, for the Lord's (Cause)

Be patient and constant.

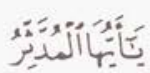

Al Muddaththir (74:1-7)

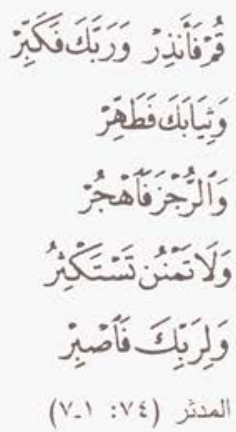

We find in the above verses that the Qur'an speaks of cleanliness and purity in a physical, moral, and spiritual sense. This is made clear in the case of the physical deviation, spiritual abomination, and the moral pollution of homosexuality of Lüt's people. In the same sense, the Qur'an speaks of keeping mosques and places of worship clean. Cleanliness here is both moralspiritual and physical.

The Qur'an combines and relates the physical and spiritual dimensions. In the above verses, we find the Qur'an speaking of the time when the Prophet was called upon to begin delivering the message of Allah to his people. In order for him to do this, he must first be clean, both physically and spiritual- 
ly, which Allah informs him of in one verse. Allah orders the Prophet to keep his outer and physical appearance clean (i.e., keep his clothing clean) and then tells him to keep his inner and spiritual self clean by getting rid of and thereafter avoiding all wrongful, sinful, and filthy qualities.

As for Lūt's people and their homosexuality, the Qur'an speaks of cleanliness in a way that combines both physical and spiritual cleanliness. The Qur'an describes their acts and behavior as wicked (sayyiah) and as a transgression (făhishah). Despite the sin which surrounded Lüt and his family, they kept themselves pure or clean (yatahharün). Here, purity and cleanliness is both spiritual and physical.

Tirmidhī narrated that Saad ibn Abū Waqqãs reported that the Prophet said: "Allah is good and loves good things; (Allah is) clean (and) loves cleanliness (nadhäfah); (Allah is) charitable (and) loves charity; (Allah is) generous (and) loves generosity. Clean the yards of your homes and the open spaces and (in this manner) do not behave like the Jews."

Imām Muslim narrated that Abū Mūsā al Ash'arī relates that the Prophet said: "Cleanliness (tahür) is the other half of faith (ìmān)."

Abū Dāwūd and al Nasāī narrated that Jābir ibn 'Abd Allāh said that the Messenger of Allah saw an unpresentable person (ash'ath) and said: "Could not this (person) find something with which to keep his hair orderly and presentable (yusakkin)? Could not this (person) find something with which to wash his clothes?"

Tirmidhī reports that the Prophet said: "There are five innate acts (fitrah): removing one's pubic hair (istihdād), circumcision, trimming one's moustache, removing one's underarm hair, and trimming one's nails."

Al Bukhārī narrated that Abū Sa'īd al Khudrī reported that the Prophet said: "Bathing on Friday is an obligation (wäjib) for all Muslims who have attained puberty."

Tirmidhī and Abū Dāwūd narrated that Salmān said: "I have read in the Torah that the blessing of food is to wash (wudū) after it. When I told the Prophet what I had read, he said: 'The blessing of food is washing before it and washing after it."”

Imām Muslim related that Abū Hurayrah said: "The Messenger of Allah saw some phlegm at the mosque's qiblah. He turned to the people and asked: 'What kind of person would stand facing his Lord and spit phlegm in front of Him? Would anyone like someone to face him and have phlegm spat in his face?"

Al Bukhārī, Tirmidhī, and Nasā̄i narrated that Umm al Mu'minīn 'Ä'ishah said the Prophet said: "Brushing the teeth (siwāk) purifies the mouth and pleases the Lord."

The above traditions and many others emphasize the importance of cleanliness and go into great detail regarding the different aspects of personal 
and environmental health and cleanliness. No doubt these traditions sharpen the Muslim's sense of physical cleanliness.

Al Bukhärī and Ahmad narrated that Ibn 'Abbās said that once the Prophet passed by two graves. He said: "They are suffering punishment, but not because of a major sin (kabirah). One is being punished for not cleansing himself after urination (yastanzih), and the other is being punished for spreading slanderous comments and misinformation among people."

Imām Mālik in his al Muwatța' narrated that the Prophet said: "Whenever defalcation and embezzlement of public funds and trust (ghulül) become widespread and common among a people, fear will be thrown into their hearts. Whenever adultery (zinā') [al Hākim narrated in his al Mustadrak that fähishah, which covers all kinds of sexual deviation in addition to both adultery and homosexuality] spreads widely and openly $(f a \bar{s} h \bar{a})$ in a people, death would greatly increase. Whenever people cheat in weighing and measuring (in commercial deals), their prosperity will cease. Whenever people rule unjustly, bloodshed (killing) will spread among them. Whenever people habitually do not fulfill their pledges (commitments), Allah will make their enemy prevail over them."

Ibn Mājah narrated a similar tradition which describes the phenomenon of făhishah in more detail: “. . . whenever deviant sexual behavior (i.e., homosexuality and adultery) spreads widely and openly, such a people will be cursed because of it and a plague (widespread mysterious death) and diseases $(a w j \bar{a})$ which were not known to their ancestors will spread widely among them..."

In the above traditions, we see that the Sunnah follows the same Qur'anic line of approach, for it addresses cleanliness from all aspects-spiritual, moral, and physical. Imān relates to inner and outer cleanliness. The absence of physical cleanliness due to urination is as bad a sin as the moral and spiritual impurity caused by spreading slanderous comments and misinformation. Both homosexuality and adultery are morally, spiritually, and physically filthy and thus lead to physical, moral, and physical harm and diseases.

Imām Muslim narrated that Umm al Mu'minin 'Ā'ishah said: “The Messenger of Allah prohibited (Muslims) from drinking from the mouths of water skins or drinking pots (siq $\bar{a}$ ) because it gives them a bad smell and causes them to rot and decay (yuntin).

Imām Muslim related that Abū Qatādah said: "The Prophet prohibited (Muslims) from breathing back into their drinking and eating utensils."

Imām Muslim also reported that Jābir ibn 'Abd Allāh related that the Prophet said: "Cover your food utensils and tie your water skin. There is one night every year during which a plague spreads (yanzil). It falls into every uncovered utensil or untied water skin."

Al Bukhārī and Imām Muslim narrated that 'Abd al Raḥmān ibn 'Awf 
reported that the Prophet said: "If a plague spreads in an area where you are staying, do not leave and run away from it. If you hear that it is spreading in certain areas, do not go to it."

Five of the six major hadith collections narrate that 'Abd Allāh ibn 'Umar said: "I heard the Prophet, when he asked about water in open places from which wild animals have drunk, say: "If the water measures two qullah (big size water-skins), it is not filthy."

Al Bukhārī narrated that Umm al Mu'minīn Maymūnah said: "A mouse fell into some ghee and died. When the Prophet was asked about it, he said: "Throw it and what is around it away, and then use the rest." Ahmad and al Nasāî added "in solid ghee."

Al Bukhārī also narrated that Anas said: "A man came to the Prophet and said: 'O Messenger of Allah. The donkeys are eaten.' The Prophet kept silent. Then the man came a second time and said: 'The donkeys are eaten,' and the Prophet kept silent. Then the man came a third time and said: 'The donkeys have perished.' The Prophet orderd a man to call out to people and say that 'Allah and His Messenger prohibit you from eating domesticated donkeys." In another narration, it is related as: "It is filth (rijs). The cooking pots were spilled while boiling the meat." The term rijs is mentioned here because it is possibly spiritually and morally wrong to eat donkey meat, since it is not in the interests of the Muslims to continue to eat it.

Abū Dāwūd narrated that Ibn Ghālib said: "O Messenger of Allah. We are hit with drought. I have nothing to feed my family except fat domesticated donkeys, and you have prohibited the eating of domesticated donkeys." The Prophet said: "Feed your family except from your fat domesticated donkeys."

$\mathrm{Al}$ Bukhārī and Muslim narrated that the Prophet said: "If it would not cause my people (ummah) difficulty, I would have ordered them to brush their teeth at every time of prayer."

In all of the verses and traditions quoted above and many others spread throughout in the Qur'an and the books of hadith, there are a few important lessons:

1. There are many issues which scientists and social scientists should study and analyze, such as the meaning of cleanliness, the ways and means to achieve and enhance the sense and practice of cleanliness - the inner and outer dimensions as well as spiritual, moral, and physical cleanliness.

2. The Prophet was very concerned about cleanliness in all of its aspects and provided attainable ways and means for people without any scientific knowledge to achieve a remarkable standard of health and cleanliness.

3. The Prophet was fully aware of the effect of unhealthy personal and 
environmental practices which destroy health and spread infectious diseases.

4. The directives of the Qur'an and Sunnah are comprehensive and civilizational and develop the sense of maintaining good health and a beautiful and healthy environment.

5. The directions of the Prophet provide all necessary and possible fundamental principles and basic means to provide all possible means of protection for the people.

6. Comparing the Qur'an's and the Sunnah's approach to health and cleanliness with the juristic approach, it is clear that both sources use an approach which is civilizational and comprehensive, one which addresses the issues of purity, good health, and a beautiful and clean environment. The juristic approach, on the other hand, is in many ways formal, static, and ritualistic. It also in many ways waters down the civilizational aspect to the point where it becomes possible for committed Muslims who are regular in their prayers and maintain the juristic rituals of cleanliness (tahärah) to be lacking in the civilizational sense of cleanliness. This appears in their personal practice, appearance, and environment so much so that it is not surprising to find the washing areas in those mosques which are usually attended by "the good Muslims" unclean.

7. When browsing through books of jurisprudence, the narrow, static, and formalistic approach (especially of the later and contemporary jurists) becomes very clear. These works are mere repetitions of texts written over a thousand years ago. No trace of the vast amount of scientific information connected with health and protection against deadly and infectious diseases can be found in even the most recent works.

8. The works of fiqh represent the historical manuals of Muslim education. Unfortunately, an educational approach or presentation is not found in these works; the contemporary works are purely legal and formal manuals deepening the secular separation of the religious and juristic from the worldly and scientific.

In conclusion, it is important for the Muslim religious scholars, social scientists, and intellectuals to recapture the civilizational aspects of Islam. They have to provide and establish the shuratic (consultative) dynamic institutions of Islamic legislation and ijtihad (Islamic creative thinking) and put an end to the secular approach towards life now found in the Muslim countries by integrating, utilizing, and addressing relevant contemporary knowledge, ways and means, and issues.

Muslim religious scholars, scientists, and intellectuals have to rewrite our fiqh manuals and make sure that our new manuals recapture our Islamic civilizational and educational needs. 